\title{
ROLE OF NGOs IN BIODIVERSITY CONSERVATION: A SITUATIONAL ANALYSIS
}

\author{
Nanjunda $D C^{*}$
}

\begin{abstract}
India has experienced serious deforesfation during the last century and it is anticipated that by the year 2035 India will be almost devoid of forests. NGO's have gained popularity in various parts of India by initiatives to conserve biodiversity such as establishing forest reserves and through the mobilisation of indigenous organisations and development. However, the relationships that emerge among NGOs, Govt. and indigenous people with regard to conservation and control over biodiversity is problematic and co-management of established forest reserves often failed, because indigenous ways of use and control of biodiversity were difficult to accept by some conservation organisations. More importantly, there is the claim that NGO's have been working to create dependency while mobilizing indigenous organisations with assistance of Western donors. Recently, to face mainstream conservation models various NGOs are launching awareness movements. These NGOs movements emphasize a coevolution between local biodiversity, indigenous ecological practices, culture and self-development.
\end{abstract}

* Project Director, Center for Advanced Rural and Tribal Policy Innovation and Management, Kushahnager-34, Kodagu Dist, Karnatako-India.

Mailing Address: Dr. Nanjunda D C, No.29, 8th Cross, Udayagiri ist Stage, Mysore-19, Karnataka-India E-mail-ajdmeditor@yahoo.co.in Cell-09880964840 


\section{Introduction}

NGOs have gained in popularity in India through initiatives to conserve biodiversity such as establishing forest reserves and through the mobilisation of indigenous organisations and development. However, the relationships that emerge among NGOs and indigenous people with regard to conservation and control over biodiversity is in some cases problematic. Co-management of natural resources often failed, because indigenous ways of use and control of biodiversity were difficult to accept by some conservation organisations.

While the need to conserve biodiversity's generally accepted worldwide, what is occupying the debates of the international community are the questions of 'how' do we conserve biodiversity and 'for whom'? This debate is clearly evident in the continued loss of biodiversity, especially in the rich biodiversity countries of the world, notwithstanding the efforts of many conservation agencies, governments, non-governmental organisations as well as individuals.

India located in the southern Asia covers many degrees of latitude, which provide a wide range of natural habitats. Forests, of which 60 percent are native forests, cover nearly half of the total surface area. The native forests constitute the oldest and most unique temperate ecosystems in the Southern Hemisphere and are an integral part of the country's development since the occupation by indigenous community's right through to the present day. However, southern India has experienced serious deforestation during the last century, mainly due to the impacts of exploitative land use practices. According to a study conducted by the report about $50-80 \%$ of natural forests were destroyed between 1984 and 2005 , and it is anticipated that by the year 2025 India will be totally devoid of natural forest at the current rate of destruction. (Calvin, 1997).

'In order to ensure the best performance of the country and its effective involvement in the international process, the NGOs should have their representatives in the national delegations at the Convention flora in the concerned countries. These representatives should be selected on the basis of objective criteria and by competency by the NGO community itself. Their role in the international process will solely and only contribute to the better participation of the country in the initiatives, and also will strengthen the positive image of this country in the international environmental community. In our opinion, a competent participation of NGOs in the international process may play the role of the best feedback'. (International Bio Conservation Society, 2005). 


\section{Convention of Biodiversity}

Among the most positive examples in the world practice is the role of the NGOs as a mediator between the governments and the representatives of the bio resource consumer industries. In such a role, the NGOs have proven their ability to conduct a constructive dialogue, to seek and find solutions on the basis of which to integrate the principles of the Convention into the activities related to use of biodiversity.

Numerous NGOs have been working towards find a solution to the various biodiversity problems. According to the latest report, more than 0.5 million grassroots workers are working in different corners of India on various ecological issues. Many NGOs have grown in size and capabilities conducting research and training's while developing effective and innovative programmes to shiff from eradication to conservation of biodiversity. The work of NGOs in the fields of environment education, tribal development, micro-financing, and alternative income generation programmes have also made important contribution in the effort to eradicate rural and tribal poverty in both urban and rural India which play a vital role in the natural conservation process. However, unless NGOs make significant improvement in their performance in promoting sustainable livelihood for the poor their best efforts may not prove sufficient for ending biodiversity degradation.

With a view to having a holistic approach to the task of ensuring sustainable development of land, the Environment Ministry has recently established a new department known as the "Department of Land Resources". This will facilitate coordinated policy intervention as well as quality improvement in area Ecology Conservation Schemes. Non-govèrnment organizations, self-help groups and Panchayati Raj Institutions have been accorded adequate role in this new initiative. In order to improve the quality of life of the rural and tribal poor and to ensure equal and effective participation of the people in the various forest policies, the restructured programmes will help functionaries at various levels in responding better to the needs at the field level. Despite the formation of specific policies and projects for dealing with conservation and the implementation of a large number of programmes by the Government and NGOs in pursuance of these policies, the impact forest destroy in the country has not been minimal. The basic reason for the failure of many programmes is that they are simply not designed to do so. All programmes, which will be implemented by the NGOs, should be geographically and culturally specific (Prout, 2005). 
As long as poverty (both rural and tribal) continues to exist it would be difficult to save forest. Simple legislation/programmes is not enough. Since acute economic crisis is the prime reason behind this problem all NGOs must and should think rather than to provide some alternative income generation programme to assisting producers organizations. If NGOs seriously wants to be in this field and, if so, necessarily specialize and they should think much larger scale programmes and project. Not only this, they should have high quality of human resource to mange themselves as organizations and their operations in a more.

NGOs should require long term multipronged strategy to be carried out on a continuous basis regrind various ecological issues. Although at policy level NGOs have been perceived as developmental agents, yet the scene at the grassroots level is not always in consonance with this subjectivity. It is so because base level Government functionaries some time see NGOs workers as outside encroaching/ occupying their space. And on other side few NGOs thinks different Government agencies are the main hurdles in their way. This may be the major weakness of many NGOs Their mutual interactions and even collaboration makes the effort more effective.

Here both Government and voluntary agencies should change their attitude and should be complimentary to each other and must take confidence in each other. NGOs should make a lot of homework in making people's participation in environmental educating and training to improve their of professional skills, overcoming behavior and cultural resistance of communities may be preferably involved in tackling the problem of environment and always they should try to became closer to the local people. Many NGOs believe economic compulsion is only the main reason for rapid forest degradation. The recent survey shows that more than $71 \%$ of the family is complexly based on the forest economy. Hence, all NGOs must think in the way of giving more and more low cost job oriented education and their by encouraging more women joining the work force besides empowerment of women would go a long way in elimination of rural and tribal poverty which indirectly plays a vital role conservation activates.

Since many parents do not under stand the significance of the Environmental Education, NGOs have to work to create awareness about the value of the environmental education among the rural and tribal folks. As soon as possible NGOs should open Ecology Centers where any school going child can come and get help to complete knowledge under the guidance of a trained teacher, and Community Play Centers where all children come and can play any eco-friendly games which enhance their knowledge about the Nature. All children would have certain inherent skills. It is necessary to equip with certain skills suited their aptitude, 
NGOs should conduct most advanced type environmental friendly training courses and must be more suitable to the rural and tribal youths. So that in the future they can appointed as forest savers. These courses should be suited for the youths who combine with normal studies. Also in order to provide opportunity to working girls for supplementing the family income NGOs should take some step to develop more non forest based tribal co-operative societies. Through this, young working girls having responsibility for organizing training, making raw material, available and selling the products goods to the market (Datta ,2001).

\section{Learning from Others}

Organizations like ROAD, PRADAN, CIST, CARE etc are some of the important NGOs working on Ecological Issues and have valuable lesson from the field to others. Especially Rural Organization for Appropriate Development (ROAD) a Mysore- (Karnataka) based NGOs has successfully implemented all above mentioned programmes in its working area. But before learn any thing from others they have to concede that the work being done by agencies is addressing the same various conservation issues as the NGOs are trying to grapple with. But it is important to note that, each NGOs will have different ideas regarding poverty focus, community acceptance, beneficiary owner ship, funds, human resource, planning strategies-etc.

\section{Resources from the Mainstream}

\section{Finance}

Since almost all NGOs is totally depend on either foreign or Indian grants for their activities, it is necessary to rise capital from mainstream sources, such as the development financial institutions and the bank. If so it will have two benefits; first it will make NGOs more accountable in terms of effective use of money ad also it opens much larger sources of funds that foreign and Indian grants. Almost allfinancial institutions like SIDBI, ICICI, NABARD, IDIBI have by accumulated years of experience in funding NGOs through grants for experimental projects NGOs can approach these institutes to get fund as loans with longer than normal repayment and moratorium periods and lower interest rate or they can rise money from the corporal sectors.

\section{Human Resources}

NGOs are known to have highly experienced and committed individuals. Many NGOs have good grassroots worker but not at middle levels. If so, the grassroots 
worker may not get any guidance and support. So NGOs should hire more experienced persons in rural poverty, Anthropologists and experts in other related field. If NGOs would like to move from direct implementing agencies to supporting producers organization, they need to have higher caliber of people at all levels is accentuate. Those in support roles have to be more versatile, having broad-based knowledge of various fields that impinge on conservation programme.

\section{Technology}

As another step towards effectiveness in rural and tribal poverty eradication programmes NGOs need to have link with various technology generation institutions blessed with a very large scientific and technological research infrastructure in India. For example ICAR, ICMR, CFTRI in addition to state level research and training institutes. Since conservation issue is related to more than one field NGOs should get a lot of technical support from these institutions. The presence of professionally trained staff in NGOs greatly facilitates this process of acquiring technology and adaptation to the local situation and to the poor rural poverty families. Training should be relative to the ground situation and executed by the professionals only. Training techniques have to be related to the experience of the participants and must simultaneously appeal to their thinking and emotions. Behavioral games; stimulation's and case study basses discussions are some useful techniques and visit to other organizations will be also be useful.

\section{Expertise}

NGOs should have a vast pool of technical experts and professionals specialized in project finance, socio-economic analysis, micro finance, training and capacity building, technical aspects, computing, rural infrastructure, rural financial institutions, planning, monitoring, evaluation, etc.

\section{Knowledge}

As rural poverty is a complex phenomenon all NGOs should have certain useful concepts which have a bearing on successful rural poverty eradication programmes - like,

1. NGOs should understand social structure, caste and class problem, dynamic of social changes, political economy of forest resources and police analysissocial science; 
2. communication theory; diffusion of innovation; group dynamics and collective action; training and organization development; and any appropriate eco friendly technology;

3. eco-competitive behavior of firms; resource and ecological economics; social cost benefit analysis-economics;

4. Accounting and finance; marketing management, eco information systems.

\section{Potential of NGOs to Assist in Drafting the National Policy on Climate and Biodiversity Change}

NGOs should take part in the activities of the Interdepartmental Committee on Climate;

NGOs should take part in the working group(s) on the project discussed with at least incumbent representatives;

NGOs should develop a mechanism to inform each other on issues of climate change, and should develop a system for awareness and discussions on the subject with the participation of any interested and potentially concerned social groups;

NGOs are ready to participate in a public debate on the development of a single national policy on climate change.

Apart from these, Experts feels NGOs can play a vital role in the Development of strategies, Framing t of regulatory framework, Carrying out of direct conservation activities, Monitoring of the biological diversity, Participation in enforcement of the legislation and assistance to the government institutions, Opponent against actions leading to breach of the principles of the Convention, Popularizing the principles of the Convention and education (Eggan, 2001).

\section{Conclusion}

In this paper a strong argument has been made that Environment related NGOs should re-examine their approaches in this field due to its inherent complexity and difference rather than relief and welfare programmes. They should exclusively focus on rural and tribal poverty related issues. Because more than $70 \%$ of our rural and trial folks life is running on forest based economy. If these kinds of NGOs could succeed in promoting sustainable livelihood for the rural and tribal poor, so that they can develop requisite level of expertise in rural poverty related sub sectors. 
And NGOs must think of much larger scale projects and draw financial and human resource from the mainstream. Policies and projects should adopt a holistic approach, taking in to the consideration socio economic set-up of working area. They should also enter into collaborative relationships with Government agencies and otherNGOs. NGOs have to try hard to solve grass-root level of problem and they should think in upgradtion of living standards and education status more particularly of the women and child who are completely based on forest based economy. More than this, NGOs should learn in employment generation in nonagricultural sectors will go a long in curbing the demand and supply of forest based goods.

\section{References}

1. Calvin (1997). Consenvation and Gender Journal of Gender Studies. Vol. 13, No. 10

2. Datta (2001). NCOs and Environment Movements in India, Tracing the Root of the Problem, IASSI Quarterly. Vol.1 1, No. 3

3. Eggan (2001). Sociological Prospective of Medical Tourism, Wind Publication: USA

4. Krishna (2005). Ecological cal issues in India, Indian Journal of Social Science., Vol.18, No. 6, pp34-43

5. Prout (2005). Ecology, NGOs and the State, Environmental Economic Review. Vol. 22, No. $8, \mathrm{pp}-23.30$ 